\title{
Comparative analysis of the properties of composite mortar with addition of rubber powder from worn tires
}

Análise comparativa de propriedades de argamassa mista com adição de pó de borracha de pneus inservíveis

\begin{tabular}{r}
\hline \\
José Aparecido Canova \\
Escola de Engenharia \\
Universidade Estadual de Maringá \\
Avenida Colombo, 5790, Campus \\
Universitário, Bloco 11, sala 9 \\
Maringá - PR - Brasil \\
CEP 87020-900 \\
Tel.: (44) 3224-0243 \\
E-mail: jacanova@uem. br \\
Rosangela Bergamasco \\
Departamento de Engenharia \\
Química, Escola de Engenharia \\
Universidade Estadual de Maringá \\
Tel.: (44) 3261-4322 \\
E-mail: rbergamasco@uem. br
\end{tabular}

Generoso de Angelis Neto Departamento de Engenharia Civil, Escola de Engenharia Universidade Estadual de Maringá Tel.: (44) 3261-4322

E-mail: ganeto@uem.br

Philippe Jean Paul Gleize Departamento de Engenharia Civil, Escola de Engenharia

Universidade Federal de Santa

Catarina
Rua J oão Pio Duarte Silva, s/ n, Córrego Grande

Caixa Postal 476

Florianópolis -SC - Brasil

CEP 88040-970

Tel.: (48) 3721-5176

E-mail: ecv1-pgh@ecv.ufsc.br

Recebido em 24/05/11

Aceito em 22/02/12

\section{José Aparecido Canova \\ Rosangela Bergamasco \\ Generoso de Angelis Neto \\ Philippe Jean Paul Gleize}

$\mathbf{T}$ given the same the addition of rubber powder from worn tires at the proportions of $6 \%, 8 \%, 10 \%$ and $12 \%$ by aggregate volume. Axial compressive strength, flexural strength, deformation energy, void content, water absorption by capillarity, restrained shrinkage, and tensile bond strength were measured. The results showed that the second mortar, with rubber waste, performed better than the ripened mortar. With a reduction in the absorption of water by capillarity in the restrained shrinkage and in the void content, it maintained the tensile bond strength. The energy of deformation rose, although the compressive strength dropped.

Keywords: Tire waste. Plastering mortar. Capillarity. Deformation.

\section{Resumo}

Este estudo compara o desempenho de duas argamassas para revestimento. A primeira, produzida no traço 1:6 de cal virgem e areia (em volume), maturada. A segunda com a mesma argamassa da primeira, mas que passou pelo processo de retirada de água em estufa. As argamassas receberam o mesmo teor de cimento, compondo o traço 1: 1,5: 9 (em volume) e adições de pó de borracha de pneus inservíveis, nas proporções (6\%, 8\% ,10\% e 12\%) em volume de agregado. Determinaram-se: as resistências à compressão axial e resistência à tração na flexão, a energia de deformação, o índice de vazios, a absorção de água por capilaridade, a retração restringida e a resistência de aderência à tração. Os resultados mostraram melhor desempenho para a argamassa seca em estufa com resíduos de borracha, em relação à argamassa maturada. Com redução na absorção de água por capilaridade, na retração restringida, no índice de vazios, manteve a resistência de aderência à tração. Embora tenha reduzido a resistência à compressão, apresentou uma maior energia de deformação.

Palavras-chave: Resíduo de pneus. Argamassa de revestimento. Capilaridade. Deformação. 


\section{Introduction}

The tire has a fundamental role in modern society and is irreplaceable in the wheels of vehicles, both in road transportation of cargo and passengers. However, after it becomes useless it turns into an environmental liability. One of the impacts generated by the worn tires refers to their composition, mainly of the non-biodegradable rubber, which can be recycled or reused. Currently in Brazil, about 22 million tires are replaced per year. Of this total, $47 \%$ can be reused and $53 \%$ are considered scrap tires. Of these, only $26,5 \%$ are disposed in an environmentally responsible way, while the remaining 9 million tires are disposed of improperly (GARDIN; FIGUEIRÓ; NASCIMENTO, 2010). Some ways of minimizing the environmental impacts are to reduce the number of tires generated in the first place and to reuse or recycle the materials, reducing the extraction of natural (JANG et al., 1998).

As the tire waste is basically solid rubber, it is classified by the Brazilian norm NBR10004 (ABNT, 2004) as Class II non-hazardous waste and, when ground, it can be easily incorporated in the plastering mortar. Plastering mortar systems are important to buildings, and should meet the following requirements: capacity to absorb deformations, adhesion to the base and low or zero permeability to water (CEOTTO; BANDUK; NAKAMURA, 2005). The evaluation of other properties, such as the compressive and flexural strengths, the tension bond strength, the void content, and the restrained shrinkage is also important.

The capacity to absorb deformation is the ability the material has to deform without rupture when subjected to tensions. The use of aggregates with low deformation modulus has been assumed to be a solution for the design of composites with high strain capacity (TURATSINZE; BONNET; GRANJU, 2007; MIRANDA; SELMO, 2006). A greater tenacity of the material, obtained by the energy of deformation, means a greater capacity to absorb deformation.

The low modulus of deformation of the material should not interfere with properties such as the tensile bond strength (adhesion to the base), nor should it contribute much to the reduction of compressive and flexural strengths.

The permeability can occur by means of pressure infiltration, capillarity, or water vapor diffusion. It is assessed by the capillary absorption of water, which must be lower than the base absorption to provide protection against the passage of rainwater (VALEK; HUGHES; BARTOS, 2000). The mortars produced with a smaller water/binders ratio have capillaries of smaller diameter that are less intercommunicable (STROEVEN; STROEVEN, 2001). Another property, the drying shrinkage, is fundamental to the performance of the coating on the matter of tightness and durability. Concerning retraction, the ideal content and particle size of the aggregate allow the reduction of the paste amount, maintaining adequate workability for use.

To obtain a ready mix that had the advantage of a constant and proper composition of the plastering mortar, Canova (2002) studied the process of water withdrawal in oven from a ripened mortar of lime and sand. From the traditional process in which lime is hydrated and ripened with the sand, the simple mortar was subjected to the process of oven drying. Once the mortar was dried, the blocks were removed and the lumps were broken up. The material was sieved through a $2.4 \mathrm{~mm}$ screen and then packaged in double plastic bags. The formation of lumps was not observed after a storage time of 120 days. Thermogravimetric analysis before and after drying and also after the 120 days of storage showed no significant changes in the physicochemical properties of the mortar. Lime maintained its binding properties and the mortar showed improvement in the workability with the increase in incorporated air and kept the water retention and exudation as in the conventional mortar, reduced water absorption and cracking, produced an increase in mechanical strength and did not lead to any significant increase in the deformation modulus.

Rubber, as a highly elastic material, tends to contribute to a better deformation in the plastering mortar, thus improving the performance in relation to cracking. Studies concerning the use of rubber powder from worn tires in cement-based materials are very recent, starting with (ELDIN; SENOUCI, 1993). These researchers found reductions in the mechanical strengths of concrete. Moreover, Topçu (1995) and Toutanji (1996) found that the concrete with the addition of rubber aggregate showed elastic behavior. Hernandes-Olivares and Barluenga (2004) and Güneyisi, Gesoglu and Ozturan (2004), who worked with rubberized concretes containing silica fume, also found sharp drops in the mechanical strength.

Raghavan, Huynh and Ferraris (1998) and Turatsinze, Bonnet and Granju (2005), among others, working with incorporation of rubber aggregates, verified a reduction in the mechanical strength of mortar. Turatsinze, Bonnet and Granju

258 Canova, J. A.; Bergamasco, R.; Angelis Neto, G. de; Gleize, P. J. P. 
(2005) gave greater emphasis to the reduction in deformation modulus.

Segre et al. (2004) obtained satisfactory results when working with mortar of cement, sand, and rubber and treating the rubber to increase its adhesion to cement paste. Canova, Bergamasco and Angelis Neto (2007) began studies with the addition of rubber powder in plastering mortar.

This study aimed to compare the properties of two types of rendering mortar, one conventional and the other dried in oven, using the addition of $6 \%$, $8 \%, 10 \%$, and $12 \%$ of rubber powder from worn tires. The main focus was on the reduction of cracking in the plastering mortar, as well as on the minimization of environmental problems.

\section{Materials and methods}

The materials used in the composition of the plastering mortar were: Class 32 compound Portland cement (CP II Z - 32), common lime powder $(\mathrm{CV}-\mathrm{C})$, fine washed river sand, and ground rubber powder from worn tires with a particle diameter of less than $0.5 \mathrm{~mm}$. The characterization of the employed materials is found in Tables 1 to 5 .

The results of the chemical assay, Table 4, revealed the presence of heavy metals in the rubber residue, such as plumb and total chrome; however, after the rubber was added to the mortar, the values fell within the standard limits.

Table 1 - Physical and mechanical properties of Portland cement (CP II Z - 32)

\begin{tabular}{|c|c|c|c|}
\hline \multicolumn{2}{|c|}{ Determination } & Result & Method \\
\hline \multirow[t]{2}{*}{ Setting time } & Start & 2 hours 50 minutes & \multirow[t]{2}{*}{ NBR 7215 (ABNT, 1995) } \\
\hline & End & 7 hours 18 minutes & \\
\hline \multicolumn{2}{|c|}{ Normal consistency } & Water/cement ratio $=0.30$ & NBR 7215 (ABNT, 1995) \\
\hline \multicolumn{2}{|c|}{ Fineness (\% retained on sieve \# 200) } & 1.62 & MB 3432 (ABNT, 1991) \\
\hline \multicolumn{2}{|c|}{ Unit weight $\left(\mathrm{g} / \mathrm{cm}^{3}\right)$} & 1.45 & NBR 7251 (ABNT, 1982) \\
\hline \multicolumn{2}{|c|}{ True density $\left(\mathrm{g} / \mathrm{cm}^{3}\right)$} & 3.09 & NM 23 (ABNT, 1998) \\
\hline \multicolumn{2}{|c|}{ Compressive strength $(\mathrm{MPa})$ at day 28} & 34.7 & NBR 7215 (ABNT, 1995) \\
\hline
\end{tabular}

Table 2 - Physical characteristics of quicklime powder dolomitic

\begin{tabular}{c|c|c|c}
\hline Determination & Result & CV-C limits & Method \\
\hline Unit weight $\left(\mathrm{g} / \mathrm{cm}^{3}\right)$ & 0.96 & - & NBR 7251 (ABNT, 1982) \\
\hline True density $\left(\mathrm{g} / \mathrm{cm}^{3}\right)$ & 3.10 & - & NM 23 (ABNT, 1998) \\
\hline Fineness (\% retained) & & & \\
Sieve \# 30 & 0.7 & $\leq 5.0$ & NBR 9289 (ABNT, 2000) \\
Sieve \# 200 & 0.22 & $\leq 30$ & \\
\hline
\end{tabular}

Table 3 - Physical characteristics of the fine aggregate - fine washed river sand

\begin{tabular}{|c|c|c|c|}
\hline Determination & \multicolumn{2}{|c|}{ Result } & Method \\
\hline Unit weight $\left(\mathrm{g} / \mathrm{cm}^{3}\right)$ & \multicolumn{2}{|c|}{1.55} & NBR 7251 (ABNT, 1982) \\
\hline True density $\left(\mathrm{g} / \mathrm{cm}^{3}\right)$ & \multicolumn{2}{|c|}{2.63} & Pycnometer \\
\hline \multirow{8}{*}{$\begin{array}{l}\text { Particle size } \\
\text { distribution }\end{array}$} & Sieve (mm) & Accumulated $\%$ retained & \multirow{8}{*}{$\begin{array}{c}\text { NBR } 7217 \text { (ABNT, } \\
1987)\end{array}$} \\
\hline & 2.4 & 0 & \\
\hline & 1.2 & 1 & \\
\hline & 0.6 & 7 & \\
\hline & 0.3 & 67 & \\
\hline & 0.15 & 99 & \\
\hline & Max. dimension (mm) & 1.2 & \\
\hline & Fineness module & 1.74 & \\
\hline
\end{tabular}

Table 4 - Chemical characteristics of the rubber powder - weight in $\mathbf{m g} \cdot \mathrm{kg}^{-1}$ - analysis - atomic absorption spectrometry

\begin{tabular}{c|c|c|c|c|c|c|c}
\hline Fe & Cu & Mn & Zn & Pb & Cd & Cr (total) & Ni \\
\hline 710.00 & 52.60 & - & 646.00 & 108.00 & - & 32.00 & 4.00 \\
\hline
\end{tabular}


Table 5 - Physical characteristics of the rubber powder

\begin{tabular}{c|c|c|c}
\hline Determination & \multicolumn{2}{|c|}{ Result } & Method \\
\hline Unit weight $\left(\mathrm{g} / \mathrm{cm}^{3}\right)$ & \multicolumn{2}{|c|}{0.44} & NBR 7251 (ABNT, 1982) \\
\hline True density $\left(\mathrm{g} / \mathrm{cm}^{3}\right)$ & \multicolumn{2}{|c|}{0.79} & Pycnometer \\
\hline \multirow{4}{*}{$\begin{array}{c}\text { Particle size } \\
\text { distribution }\end{array}$} & Sieve $(\mathrm{mm})$ & Accumulated \% retained & \multirow{3}{*}{ NBR 7217 (ABNT, 1987) } \\
\cline { 2 - 3 } & 1.2 & 0 & \\
\cline { 2 - 3 } & 0.6 & 34 & \\
\cline { 2 - 3 } & 0.3 & 0.15 & \\
\cline { 2 - 3 } & Max. dimension $(\mathrm{mm})$ & 0.42 & \\
\cline { 2 - 3 } & Fineness module & 1.33 & \\
\cline { 2 - 3 } & &
\end{tabular}

\section{Mortar}

The simple mortar was produced in a 1:6 proportion of lime and sand (by volume) with $2.46 \mathrm{dm}^{3}$ of water per $\mathrm{kg}$ of lime and divided into two equal parts. The first part was packed in plastic bags and the second in covered metal recipients. Both parts were then ripened for seven days with their weights determined.

The first part of the mortar received cement composing the proportion 1:1.5:9 (cement, lime, and sand, by volume) - 1:0.993:9.623 in equivalent weight - and the addition of rubber powder contents of $6 \%, 8 \%, 10 \%$, and $12 \%$ relative to the volume of aggregate. Reference mortar was named as Am0, and Am6, Am8, Am10, and Am12 were named according to the percentage of rubber powder used. Amx refers to all the series.

The second part of the mortar was subjected to drying in an oven at a temperature of $(105 \pm 10)$ ${ }^{\circ} \mathrm{C}$ until constant weight. The dry mortar weight was determined and the procedure was carried out as in Canova (2002), with storage for a period of 60 days. Cement and rubber powder were then added in the same proportions as for the first mortar. The same naming procedure was followed for this mortar, only replacing the letter " $\mathrm{m}$ " with the letter "s".

\section{Measured properties}

The properties were evaluated via laboratory testing according to ABNT (Brazilian Technical Standards Association). The axial compressive strength, the deformation energy, the void content, and the water absorption by capillarity were all evaluated in cylindrical specimens with $5 \mathrm{~cm}$ in diameter and $10 \mathrm{~cm}$ in height and tested at day 28 . The flexural strength and the restrained shrinkage were evaluated in prismatic specimens. The tensile bond strength of the substrate was also evaluated.

- Axial compressive strength - it was measured according to procedures of NBR 13279 (ABNT, 1995) and NBR 7215 (ABNT, 1995).
- Flexural strength - the procedure was adapted from the ISO/DIS 679:1993. Molds measuring 200 $\mathrm{mm}$ in length, $75 \mathrm{~mm}$ in width, and $25 \mathrm{~mm}$ in depth were used in triplicate. The tests were performed at day 28 with the application of a uniformly distributed load on the middle cross section of the bi-supported specimen. The tensile stress in bending is given by Equation 1, where:

$\sigma=1.5 \mathrm{PL} / \mathrm{bd}^{2}$

Eq. 1

$\sigma=$ tensile stress in bending (MPa);

$\mathrm{P}=$ load applied in the middle of the prism $(\mathrm{N})$;

$\mathrm{L}=$ distance between supports $(160 \mathrm{~mm})$;

$\mathrm{b}=$ larger side of the specimen cross section $(\mathrm{mm})$;

$\mathrm{d}=$ specimen depth $(\mathrm{mm})$.

The $160 \mathrm{~mm}$ distance between the supports of the specimen was the same as in ISO/DIS 679 (ISO, 1993). A load application rate of $0.02 \mathrm{MPa} / \mathrm{s}$ was also adopted, as in Canova (2002), due to the low strength values obtained for this mortar.

- Deformation energy during compression - the measurement was evaluated by the area under the tension vs. deformation curve in compression tests run in a simple compression machine.

- Void content - the analysis was based on the NBR 9778 (ABNT, 1987) procedure.

- Water absorption by capillarity - the measurement was based on the NBR 9779 (ABNT, $1995)$ procedures, but changes in the reading times were needed - chosen times were as follows: every 10 minutes up to minute 90 , every 15 minutes from minute 90 to 150 , every 20 minutes from minute 150 to 360 , every 45 minutes from minute 360 to 450 , and every 60 minutes from minute 450 to 1350 . Marks were made every $1 \mathrm{~cm}$ high in the specimen to monitor its surface moisture. These marks were made along three generatrixes to facilitate the reading.

- Drying retraction with one restrained side - in this experiment, where specimens were used as coating simulation, the influence of the base on the

260 Canova, J. A.; Bergamasco, R.; Angelis Neto, G. de; Gleize, P. J. P. 
water loss to filter paper and on the adhesion of the mortar on the metal grid was simulated.

The procedure used was similar to that of Lejeune (1995). This kind of experiment was accomplished to observe the restrained shrinkage, which is the deformation measured in mortar immediately after demolding. Specimens measuring $285 \mathrm{~mm}$ in length, $100 \mathrm{~mm}$ in width, and $25 \mathrm{~mm}$ in depth were used in triplicate. The metal grid used for mortar adhesion was $1 \mathrm{~mm}$ thick, drilled with $15 \mathrm{~mm}$ diameter round holes in approximately $50 \%$ of its area, with $3 \mathrm{~mm}$ spacing between them. Filter paper was used between the base and the metal grid, allowing water suction and mortar demolding.

Retraction measures were performed on the free, exposed to air upper side of the specimen. The specimens were kept in a dry chamber with temperature of $(23 \pm 2){ }^{\circ} \mathrm{C}$ and relative humidity of $(50 \pm 4) \%$. Readings were taken every 24 hours up to day 10 , and then at days $13,16,21$, and 28 .

- Tensile bond strength - it was determined for specimens on substrate according to NBR 13528 (ABNT, 1995). The used substrate was made with a $9 \times 14 \times 19 \mathrm{~cm}$ 6-holed ceramic block with application of an adhesion layer in a 1:3 proportion of cement and sand (by volume). The plastering was made in $1.0 \mathrm{~m}^{2}$ panels, in $1.5 \mathrm{~cm}$ thick single layers, for each one of the rubber powder contents. The determination was made at day 91.

\section{Results and discussion}

The consistency index, specified by NBR 13276 (ABNT, 1995) between 245 and $265 \mathrm{~mm}$ of scattering, was determined with the flow table test. The results, presented in Table 6 , characterized the workability of each mixture and identified them as suitable for application as plastering mortars.

\section{Comparing the axial compressive strengths}

In Fig. 1, the same trend of reduced compressive strength is observed for both mortars, though it was more pronounced for the ripened mortar as compared to the oven-dried mortar. The difference was close to $4 \%$ for the reference mortar and reached $14 \%$ for the mortars with $12 \%$ of rubber powder.

\section{Table 6 - Proportion parameters of the mortars}

\begin{tabular}{|c|c|c|c|c|}
\hline Mortar & $\begin{array}{l}\text { Consistency index } \\
255 \pm 10(\mathrm{~mm})\end{array}$ & $\begin{array}{c}\text { Water/dry materials } \\
\text { ratio (mass) }\end{array}$ & $\begin{array}{l}\text { Water/cement } \\
\text { ratio (mass) }\end{array}$ & $\begin{array}{l}\text { Water/binders } \\
\text { ratio (mass) }\end{array}$ \\
\hline $\mathrm{Am} 0$ & 257 & 0.250 & 2.89 & 1.435 \\
\hline Am6 & 255 & 0.235 & 2.77 & 1.370 \\
\hline Am8 & 254 & 0.234 & 2.77 & 1.370 \\
\hline Am10 & 260 & 0.233 & 2.77 & 1.370 \\
\hline Am12 & 250 & 0.232 & 2.77 & 1.370 \\
\hline As0 & 254 & 0.231 & 2.64 & 1.328 \\
\hline As6 & 250 & 0.226 & 2.60 & 1.303 \\
\hline As8 & 252 & 0.224 & 2.60 & 1.289 \\
\hline As10 & 253 & 0.223 & 2.60 & 1.289 \\
\hline As12 & 251 & 0.222 & 2.60 & 1.289 \\
\hline
\end{tabular}

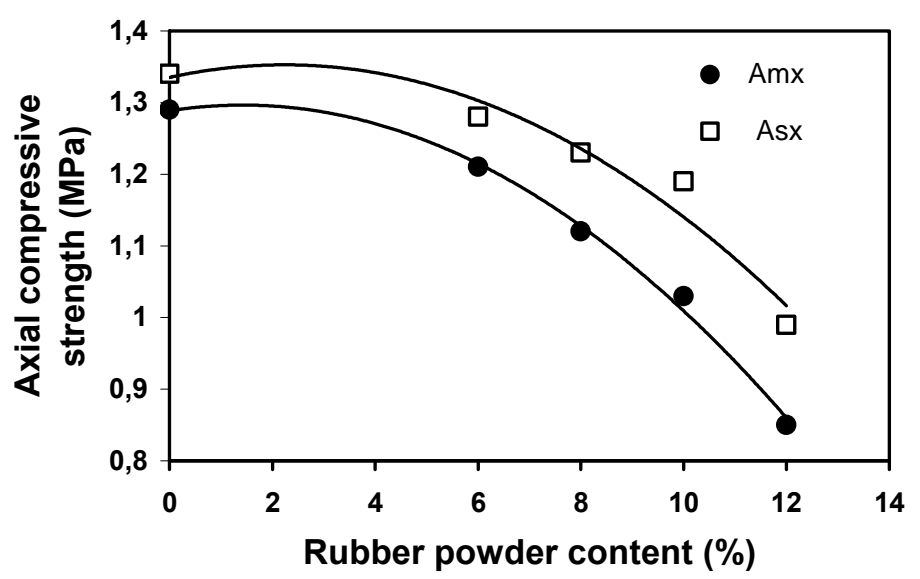

Figure 1 - Axial compressive strength for mortars Amx (•) and Asx (口) 
The lower water/binders ratio and the lower water demand for the oven-dried mortar to return to the plastic state, contributed to the increased axial compressive strength. The still lower water/binders ratio for the mortars with rubber powder addition led to a progressive increase in the difference in strength between the two mortars with the same level of addition.

The rubber powder was used in mortar as an addition to the aggregate volume that has increased the volume of mortar in the plastic state relative to the reference mortar and contributed to a further reduction in axial compressive strength. This contribution was found to be of $2 \%$. In considering this difference, it was observed that the strength of the oven-dried mortar with $8 \%$ rubber powder practically equaled the strength of the reference mortar. It was verified, though, that the major influence on the reduction in axial compression strength was from the low specific gravity of the rubber.

\section{Comparing the flexural strengths}

One can see in Fig. 2 that the flexural strength was also higher for the oven-dried mortar than for the ripened mortar. This increase is due to the reduced water/cement ratio of the oven-dried mortar when compared with the ripened mortar. It is assumed that the air incorporated into the dry mixture and the air trapped inside the grains, as well as the nontotal water absorption of the grains, contributed to that reduction. The increase in flexural strength was of $5 \%$ for the oven-dried mortar with a rubber powder content of $6 \%$, but reached $11 \%$ in the mortar with a rubber powder content of $12 \%$.

\section{Comparing the deformation energies during compression}

Comparing the deformation energies in Table 7 , one can observe that the energy calculated for the 1.5 $\mathrm{MPa}$ stress was greater in the mortars with added rubber powder, proving the greater elastic energy of rubber.

The oven-dried mortar presented, for the same stress, higher deformation energy values than the ripened mortar. This was observed in the reference mortar as well as in the mortars with rubber powder addition. However, although the ovendried mortar presented higher final strengths, there was a change in its internal structure, showing greater deformation than the ripened mortar.

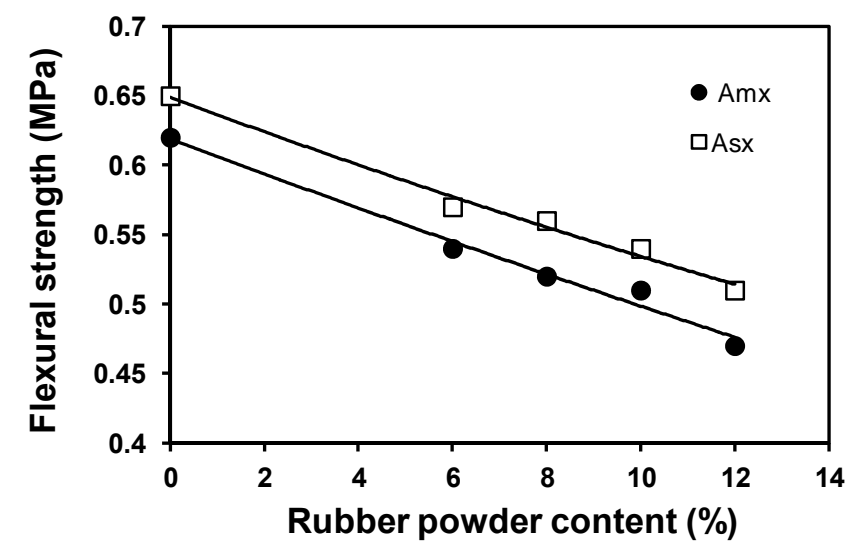

Figure 2 - Flexural strength for mortars Amx (•) and Asx ( $\square$ )

Table 7 - Mortar deformation energy test results

\begin{tabular}{c|c}
\hline Mortar & $\begin{array}{c}\text { Deformation energy during } \\
\text { compression (MPa.mm) }\end{array}$ \\
\hline $\mathrm{Am} 0$ & 0.00689 \\
\hline $\mathrm{Am} 6$ & 0.00726 \\
\hline $\mathrm{Am} 8$ & 0.00731 \\
\hline $\mathrm{Am} 10$ & 0.00731 \\
\hline $\mathrm{Am} 12$ & 0.00749 \\
\hline $\mathrm{As} 0$ & 0.00814 \\
\hline $\mathrm{As} 6$ & 0.00834 \\
\hline $\mathrm{As} 8$ & 0.00865 \\
\hline $\mathrm{As} 10$ & 0.00886 \\
\hline $\mathrm{As} 12$ & 0.00937 \\
\hline
\end{tabular}

262 Canova, J. A.; Bergamasco, R.; Angelis Neto, G. de; Gleize, P. J. P. 


\section{Comparing the void contents at $(105 \pm 10)^{\circ} \mathrm{C}$}

Through the analysis of Fig. 3, one can verify that the oven-dried mortar showed a better reduction in the void content than the ripened mortar as rubber was added, thus closing the pore structure of the mortar. This is related to the greater reduction in the water/binders ratio of the oven-dried mortar.

\section{Comparing results of water absorption by capillarity}

One can observe in Fig. 4 that the oven-dried mortar absorbed less water by capillarity than the ripened mortar. This was observed in the reference mortar as well as in the mortars with rubber powder addition. A significant difference was observed for the mortars with $10 \%$ and $12 \%$ of rubber powder, as even the time in which water reached the top of the specimen was increased, while the specimen containing $8 \%$ of rubber powder presented the largest time to have its top reached by water.

The observed reduction in the capillarity rate was due to the lower porosity of the material, which occurred as the addition of rubber powder increased the amount of fine aggregate and reduced the water/binders ratio, with more extensive closure of the pores for the oven-dried mortars.

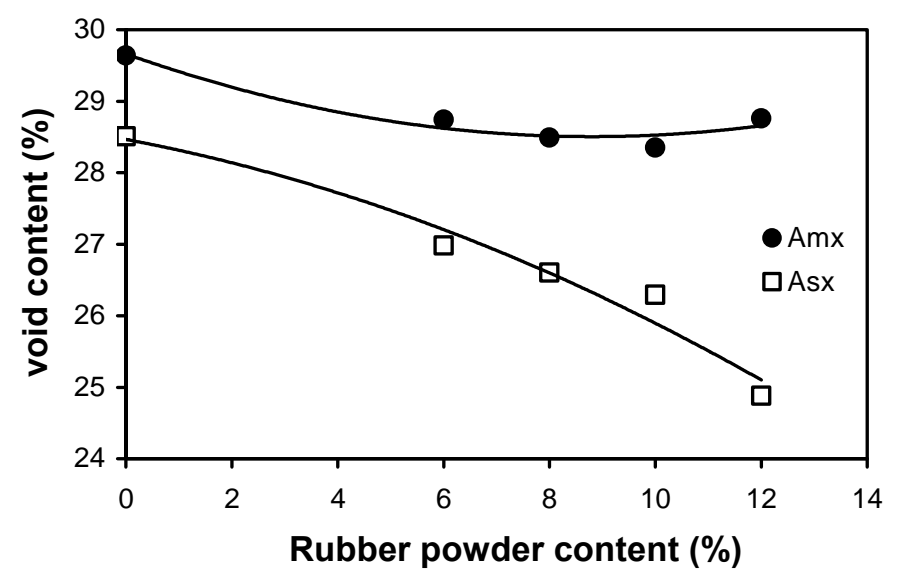

Figure 3 - Void contents for mortars Amx (•) and Asx ( $\square)$ at $(105 \pm 10){ }^{\circ} \mathrm{C}$

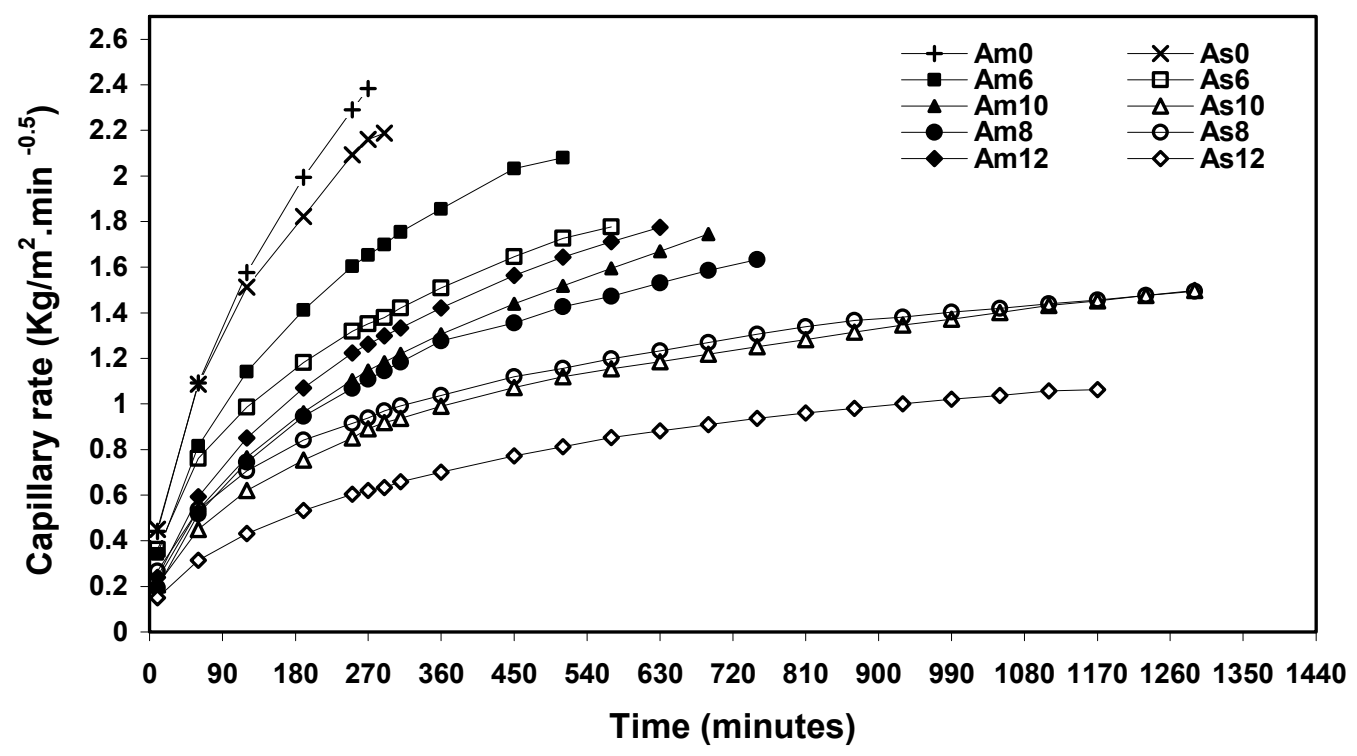

Figure 4 - Water absorption by capillarity for mortars Am0 (+), As0 (×), Am6 (匹), As6(口), Am8(०),

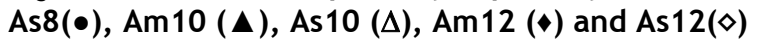




\section{Comparing the restrained shrinkages}

One can see in Fig. 5 that the oven-dried mortar presented lower restrained shrinkage than the ripened mortar. This was observed in the reference mortar as well as in the mortars with rubber powder addition. The difference between the ovendried and the ripened reference mortars was of about $17 \%$ from day 4 to day 28 after demolding. For the mortars with rubber powder, there was no significant difference up to the third day after demolding. However, at day 4 , the shrinkage of the oven-dried mortar was $6 \%$ lower than that of the ripened mortar, and at day 28 this difference went beyond $16 \%$.

The greater concentration of fine aggregate, with the addition of rubber powder, and the reduction in the water/binders ratio (especially for the ovendried mortar) are factors that contributed to a lower retraction of the mortar and a reduction of the negative effects of an accelerated drying. One could suppose that the reduction in drying retraction is an indication of a possible plastic retraction of the mortars.

\section{Comparing the tensile bond strengths}

One can see in Fig. 6 that the tensile bond strength values were similar for the oven-dried and the ripened reference mortars. The same pattern was observed for mortars with $6 \%$ and $10 \%$ of rubber powder. However, for $8 \%$ of rubber powder the ripened mortar had a 5\% lower strength than the oven-dried one, and for $12 \%$ of rubber powder this difference was of $9 \%$. This trend of increasing tensile bond strength for oven-dried mortars from $8 \%$ addition of rubber powder may have occurred because of the increased mechanical strength achieved by these mortars.

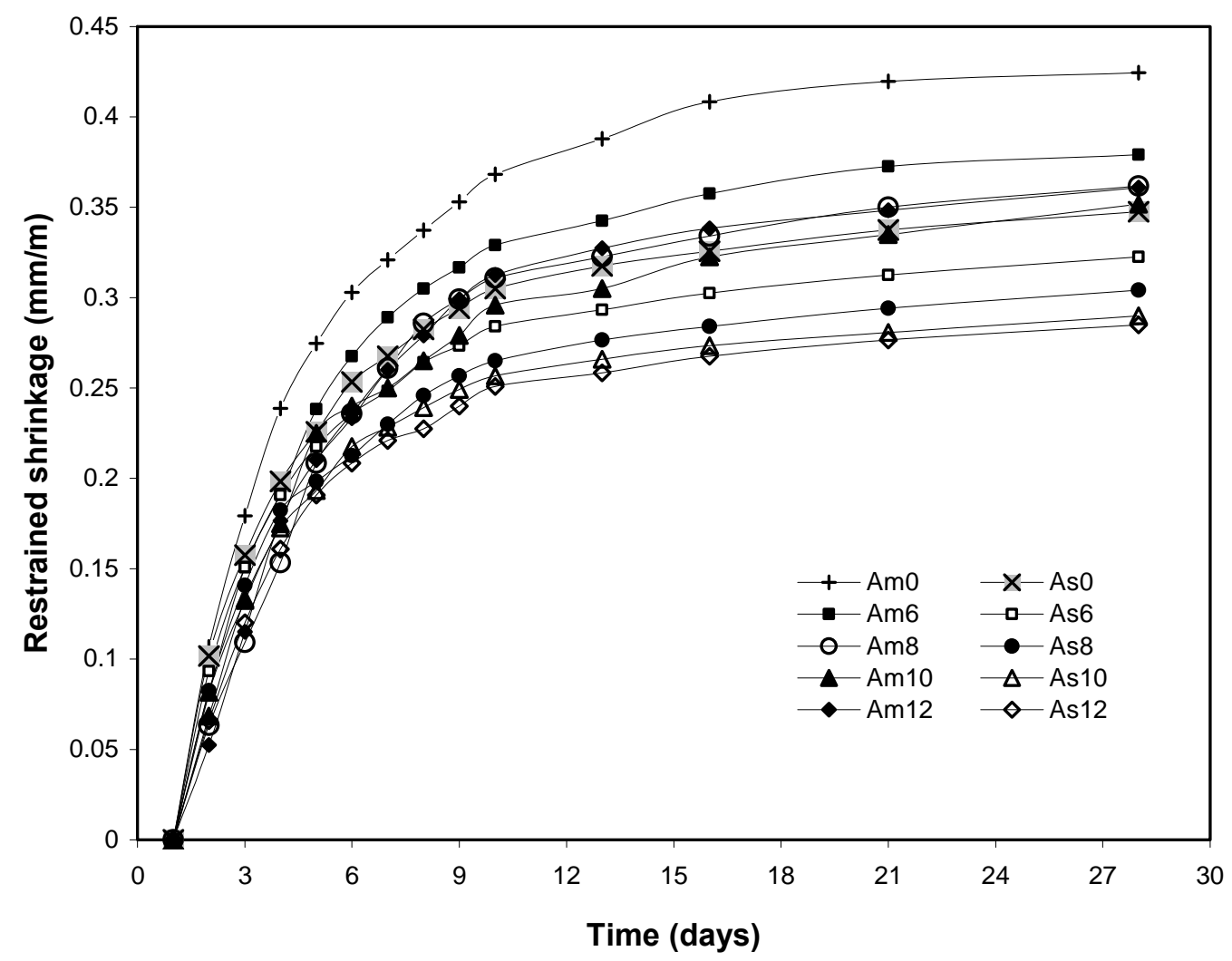

Figure 5 - Restrained shrinkage for mortars Am0 (+), As0 (×), Am6 (घ), As6 (), Am8 (०), As8 (•), Am10

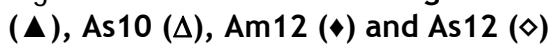




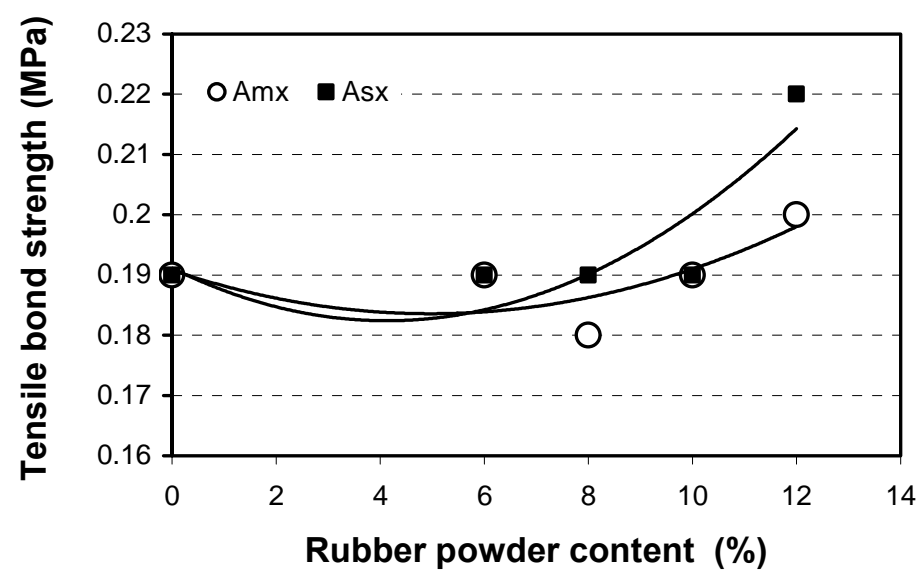

Figure 6 - Tensile bond strength for mortars Amx (०) and Asx (a)

\section{Conclusion}

The addition of rubber powder in the mortars resulted in lower compressive and flexural strengths, but contributed to higher deformation energies. However, there was no statistically significant difference in the strengths for an addition of $6 \%$ in the ripened mortar or up to $10 \%$ in the oven-dried mortar.

The rubber powder addition improved the void content, the water absorption by capillarity and the drying retraction, with better results for the ovendried mortar, particularly regarding water absorption by capillarity. As for tensile bond strength, no significant variation was observed for both mortars.

In general it is concluded that the production of rendering mortar with rubber powder addition is fully feasible up to a rubber powder content of $8 \%$ in the case of the oven-dried mortar. When using the ripened mortar, it is better not to exceed a content of $6 \%$.

\section{References}

ASSOCIAÇÃO BRASILEIRA DE NORMAS TÉCNICAS. NBR 7217: agregados em estado solto: determinação da composição granulométrica: método de ensaio. Rio de Janeiro, 1987.

ASSOCIAÇÃO BRASILEIRA DE NORMAS

TÉCNICAS. NBR 7251: agregados em estado solto: determinação da massa unitária: método de ensaio. Rio de Janeiro, ABNT, 1982.
ASSOCIAÇÃO BRASILEIRA DE NORMAS

TÉCNICAS. NBR 9779: argamassa para assentamento de paredes e revestimentos de paredes e teto: determinação da absorção de água por capilaridade: método de ensaio. Rio de Janeiro, 1995.

\section{ASSOCIAÇÃO BRASILEIRA DE NORMAS}

TÉCNICAS. NBR 9778: argamassa para assentamento de paredes e revestimentos de paredes e teto: determinação da absorção de água por imersão índice de vazios e massa específica: método de ensaio. Rio de Janeiro, 1987.

\section{ASSOCIAÇÃO BRASILEIRA DE NORMAS}

TÉCNICAS. NBR 13279: argamassa para assentamento de paredes e revestimentos de paredes e teto:determinação da resistência à compressão: método de ensaio. Rio de Janeiro, 1995.

\section{ASSOCIAÇÃO BRASILEIRA DE NORMAS}

TÉCNICAS. NBR 13528: argamassa para assentamento de paredes e revestimentos de paredes e teto: determinação da resistência de aderência à tração: método de ensaio. Rio de Janeiro, 1995.

ASSOCIAÇÃO BRASILEIRA DE NORMAS TÉCNICAS. NBR 13276: argamassa para assentamento de paredes e revestimentos de paredes e teto: determinação do teor de água para obtenção do índice de consistência-padrão: método de ensaio. Rio de Janeiro, 1995.

\section{ASSOCIAÇÃO BRASILEIRA DE NORMAS} TÉCNICAS. NBR 9289: cal hidratada para argamassas: determinação da finura: método de ensaio. Rio de Janeiro, 2000. 
ASSOCIAÇÃO BRASILEIRA DE NORMAS TÉCNICAS. NBR 7215: cimento portland: determinação da resistência à compressão. Rio de Janeiro, 1995.

\section{ASSOCIAÇÃO BRASILEIRA DE NORMAS} TÉCNICAS. NBR 10004: resíduos sólidos: classificação. Rio de Janeiro, 2004.

\section{ASSOCIAÇÃO BRASILEIRA DE NORMAS} TÉCNICAS. NBR MB 3432: cimento portland: determinação da finura por meio da peneira $75 \mu \mathrm{m}$ $\left(n^{\circ} 200\right)$. Rio de Janeiro. 1991.

ASSOCIAÇÃO BRASILEIRA DE NORMAS TÉCNICAS. NBR NM 23: cimento portland: determinação de massa específica. Rio de Janeiro, 1998.

CANOVA, J. A.; BERGAMASCO, R.; De ANGELIS NETO, G. A Utilização de Resíduos de Pneus Inservíveis em Argamassa de Revestimento. Acta Scientiarum. Technology, v. 29, n. 2, p. 141-149, 2007.

\section{CANOVA, J. A. Estudo e Análise das}

Propriedades da Argamassa de Cal e Areia Suprimida a Água da Mistura após Maturação. 98 p. Florianópolis, 2002. Dissertation (M.Sc. in Civil Engineering) - Escola de Engenharia, Universidade Federal de Santa Catarina, Florianópolis, 2002.

CEOTTO, L. H.; BANDUK, R. C.;

NAKAMURA, E. H. Revestimentos de

Argamassas. In: Habitare. Porto Alegre: ANTAC, 2005. 96 p. Recomendações Técnicas Habitare, v. 1.

ELDIN, N. N.; SENOUCI, A. B. Rubber Tire Particles as Concrete Aggregate. Journal of Materials in Civil Engineering, v. 5, n. 4, p. 478496, 1993.

GARDIN, J. A. C.; FIGUEIRÓ, P. S.; NASCIMENTO, L. F. Logística Reversa de Pneus Inservíveis: discussões sobre três alternativas de reciclagem para este passivo ambiental. Revista Gestão e Planejamento, v. 11, n. 2, p. 232-249, 2010.

GÜNEYISI, E.; GESOGLU, M.; OZTURAN, T. Properties of Rubberized Concretes Containing Silica Fume. Cement and Concrete Research, v. 34, n. 12, p. 2309-2317, 2004.

HERNANDEZ-OLIVARES, F.; BARLUENGA, G. Fire Performance of Recycled Rubber-Filled High-Strength Concrete. Cement and Concrete Research, v. 34, n. 1, p. 109-117, 2004.
INTERNATIONAL ORGANIZATION FOR STANDARDIZATION. ISO 679: methods of testing cements: determination of strength. Nov. 1993.

JANG, J. W. et al. Discarded Tire Recycling Practices in the United States, Japan and Korea. Resources, Conservation and Recycling, v. 22, n. 1/2, p. 1-14, 1998.

LEJEUNE. C. Comportement a la Fissuration dês Enduits d'Imperméabilisation. In: SIMPOSIO BRASILEIRO DE TECNOLOGIA DAS ARGAMASSAS, 1., Goiânia, 1995. Anais... Goiânia: ANTAC, 1995.

MIRANDA, L. F. R.; SELMO S. M. S. CDW Recycled Aggregate Renderings: part II: analysis of the effect of materials finer than $75 \mu \mathrm{m}$ under accelerated aging performance. Construction and Building Materials, v. 20, n. 9, p. 625-633, 2006.

RAGHAVAN, D.; HUYNH, H.; FERRARIS, C. F. Workability, Mechanical Properties, and Chemical Stability of a Recycled Tyre RubberFilled Cementitious Composite. Journal of Materials Science, v. 33, n. 7, p. 1745-1752, 1998.

SEGRE, N. et al. Rubber-Mortar Composites: effect of composition on properties. Journal of Materials Science, v. 39, n. 10, p. 3319-3327, 2004.

STROEVEN, P.; STROEVEN. M.

Reconstructions by SPACE of the Interfacial Transition Zone. Cement and Concrete Composites, v. 23, n. 11, p. 189-200, 2001.

TOPÇU, I. B. The Properties of Rubberized Concretes. Cement and Concrete Research, v. 25, n. 2, p. 304-310, 1995.

TOUTANJI, H. A. The Use of Rubber Tire Particles in Concrete to Replace Mineral Aggregates. Cement and Concrete Composites, v. 18, n. 2/3, p. 135-139, 1996.

TURATSINZE, A.; BONNET, S.; GRANJU, J. L. Mechanical Characterisation of Cement-Based Mortar Incorporating Rubber Aggregates From Recycled Worn Tyres. Building and Environment, v. 40, n. 2, p. 221-226, 2005.

TURATSINZE, A.; BONNET, S.; GRANJU, J. L. Potential of Rubber Aggregates to Modify Properties of Cement Based-Mortars: improvement in cracking shrinkage resistance. Construction and Building Materials, v. 21, n. 1, p. 176-181, 2007. 
VALEK, J.; HUGHES, J. J.; BARTOS, P. J. M.

Portable Probe Gas Permeametry in the Testing of

Historic Masonry and Mortars. In: BARTOS, P.;

GROOT, C.; HUGHES, J. J. Historic Mortars:

characteristics and tests. Cachan: RILEM

Pblications, 2000. p. 185-196.

Revista Ambiente Construído

Associação Nacional de Tecnologia do Ambiente Construído

Av. Osvaldo Aranha, 99 - 3o andar, Centro

Porto Alegre - RS - Brasil

CEP $90035-190$

Telefone: +55 (51) 3308-4084

Fax: +55 (51) 3308-4054

www. seer. ufrgs. br/ ambienteconstruido

E-mail: ambienteconstruido@ufrgs.br 